C 2021 by the author. This work is licensed under

Creative Commons Attribution 4.0 International License

https://creativecommons.org/licenses/by/4.0/

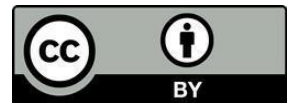

elSSN: $2708-9800$

https://doi.org/10.47316/caimhe.2021.2.1.03

PUBLICATION ETHICS

REVIEW

\title{
DISCLOSURE OF POTENTIAL CONFLICTS OF INTEREST IN BIOMEDICAL PUBLICATIONS IN VIEW OF THE INTERNATIONAL COMMITTEE OF MEDICAL JOURNAL EDITORS RECOMMENDATIONS
}

Received: Feb. 8, 2021

Accepted: March 18, 2021

Takako Kojima ${ }^{1 *}$ https://orcid.org/0000-0001-8300-2690

1Department of International Medical Communications, Tokyo Medical University, Tokyo, Japan

\section{*Corresponding author:}

Takako Kojima, Associate Professor; Department of International Medical Communications, Tokyo Medical University; 67-1 Nishishinjuku, Shinjuku-ku, Tokyo 160-0023 Japan;

Twitter handle: @kojima_takako E-mail: tkojima@tokyo-med.ac.jp

\begin{abstract}
As potential conflicts of interest (COI) are common in biomedical research, handling related issues and managing disclosures is increasingly important. The International Committee of Medical Journal Editors (ICMJE) revised its guidance on COI in 2019 and introduced the latest version of the COI Disclosure Form in 2021. These documents provide guidance regarding COI policy for ICMJE member and non-member journals. The 2019 revision overviews the main changes in the ICMJE policy. The ICMJE prioritizes appropriate COI disclosures by authors and all others involved in scholarly publishing. Increasing the global awareness of the $\mathrm{COI}$ updated policies among all stakeholders is essential for strengthening ethical standing of journals.
\end{abstract}

Keywords: Conflict of Interest, Publishing, Editorial Policies, Scientific Societies, Periodicals as Topic

How to cite: Kojima T. Disclosure of potential conflicts of interest in biomedical publications in view of the international committee of medical journal editors recommendations. Cent Asian J Med Hypotheses Ethics 2021;2(1):1822. https://doi.org/10.47316/cajmhe.2021.2.1.03

\section{INTRODUCTION}

Managing potential conflicts of interest (COI) continues to be challenging in biomedical journals. As the credibility of scholarly research depends on unbiased and transparent writing, peer review, and editorial decisions, all of which can be affected greatly by $\mathrm{COI}$, and since $\mathrm{COI}$ can arise at all stages of research and publishing [1], the integrity of scientific communication relies heavily on $\mathrm{COI}$ disclosure.

Since the early 2000s, the International Committee of Medical Journal Editors (ICMJE) has prioritized potential
COI disclosures for individual authors and all those involved in the peer review and scholarly publishing. The ICMJE stated that "public trust in the peer review process and the credibility of published articles depend in part on how well COl is handled" [2]. Nonetheless, problems with COI disclosure have persisted due to the difficulties surrounding the $\mathrm{COI}$ handling, or transparency, as the interpretations of potential $\mathrm{COI}$ depend on individual beliefs and perceptions with non-disclosure, incomplete, and inconsistent disclosures frequently encountered by editors [3]. 
To facilitate proper handling of $\mathrm{COI}$, the ICMJE introduced a uniform disclosure form in 2010 [4]. Important issues, however, remained. For example, the ICMJE recognized that the term "potential conflict of interest" was confusing to authors and readers, and that it led to misunderstandings, misapplications, and misinterpretations of $\mathrm{COI}$ disclosures $[3,5]$. To address such issues, the ICMJE updated its guidance in 2019, and introduced the revised COI disclosure form in 2021 $[6,7]$.

\section{ICMJE REVISED STATEMENTS}

Compared with the 2008 edition [8], the ICMJE Recommendations were substantially amended in 2013, especially in parts concerning authorship and COI. Authorship criteria included a fourth criterion requiring all co-authors to be accountable for all aspects of their work to ensure that questions related to the accuracy or integrity of any part of the work are appropriately investigated and resolved [9]. Furthermore, COI was now listed under the subheading "Author Responsibilities", and the concept that "perceptions of COl" are as important as actual COI was introduced [9]. Even when there is no $\mathrm{COI}$, readers may think that there is a conflict. Like actual, the perceived COI might be risky and detrimental to the public trust [10].

To enforce accurate COI disclosures, it is necessary to comprehensively and understandably define what is COI. The 2013 edition of the ICMJE Recommendations provides a succinct, clear, and detailed explanation of COl [9].

In 2018, the ICMJE revised its Recommendations by adding the statement that "purposeful failure to disclose $\mathrm{COI}$ is a form of misconduct" [11]. In the section on Publishing and Editorial Issues Related to Publication in Medical Journals, it was highlighted that scientific misconduct includes purposeful failure to disclose COI, and, in situations where there are concerns regarding such misconduct, an expression of concern may be published [11].

Until the latest revision of the ICMJE Recommendations in 2019, journals had often published corrections in cases of COI non-disclosure. However, the ICMJE now stresses that simply adding a previously missing disclosure of potential COI is insufficient. This is a move that makes it easier for journals and institutions to sanction authors who conceal potential COI [12].

The latest edition of the ICMJE Recommendations introduced several significant changes. One notable change is that the term "relationships and activities" is used along with "COl" to improve the understanding of conflicts. Authors should disclose all activities or relationships, whether financial, non-financial, personal, or institutional, that "are related to the content" of a submission. The document now stresses the importance of readers who may determine whether such "relationships and activities" have an influence on research output. Accordingly, authors should demonstrate their commitment to transparency through complete disclosure to ensure the trustworthiness of the scientific process [6]. The way things appear to readers is as important as how they actually are. With this change, final decisions about what is and what is not a potential $\mathrm{COI}$ no longer rest with authors. Readers are now entrusted with the responsibility to evaluate author disclosures of relationships and activities. Until now, authors themselves have been responsible to disclose what they perceived potentially conflicting [13]. The latest ICMJE Recommendations have encouraged all those involved in the editorial process to transparently disclose COI.

\section{DISCLOSURE FORM CHANGES}

The ICMJE first introduced its COI disclosure form in 2010, aiming to implement a uniform tool for disclosing financial and non-financial interests. This form was made publicly available on the ICMJE website. At that time, the feedback regarding non-financial $\mathrm{COI}$ disclosures was negative [14]. Specifically, there was concern about the "immense difficulty in defining $\mathrm{COI}$ beyond those that involve the direct exchange of money." This led the ICMJE to remove direct questions about non-financial $\mathrm{COI}$, as well as questions related to $\mathrm{CO}$ of authors' spouses and minor children [14].

Since the consequences of non-financial $\mathrm{COI}$ or other circumstances that may influence research are significant, the ICMJE decided to reword questions about non-financial conflicts and introduced points about any "relationships or activities" that could be perceived to influence scholarly work [14].

In 2020, ten years after publicizing its first uniform COI disclosure form, the ICMJE made significant changes to straighten the disclosure, and the new Disclosure Form was introduced in February 2021. The new form begins with the clause "in the interest of transparency" and specifically states that all relationships, activities, and interests that may affect the content of the submitted work need to be disclosed to demonstrate the author's commitment to transparency [7]. In the instructions on how to use the Disclosure Form, considerable attention 
is paid to the importance of transparency in scientific publications.

\section{IMPLICATIONS OF NON-DISCLOSURE}

As a matter of professional ethics, authors are expected to disclose potential $\mathrm{COI}$ and anything that might result in bias. All stakeholders should understand that numerous financial and non-financial (personal) conflicts accumulate over an individual's academic career. They should also admit that $\mathrm{COI}$, particularly those not obvious for readers, may have negative consequences if not properly managed [15]. Disclosed and undisclosed COI may affect the reliability of clinical evidence while the introduced biases may diminish the value of scientific research [16].

The ICMJE emphasizes that COI may also affect editorial decisions, urging responsible editors with potential COI to hand over their duties to peers. Editors control priority of articles in their journals. They ensure the journal integrity by enforcing authors' adherence to the instructions, but their own interests and biased actions are difficult to manage [17]. The peer review process and editorial decisions may be influenced by a variety of conflicting financial and non-financial relationships which most of the time remain obscure [17].

\section{PERSPECTIVES}

Managing $\mathrm{COI}$ is increasingly difficult due to the expanding relationships between researchers and sponsoring organizations. Such relationships are likely to become more complex and challenging in the future [3]. What can be done to appropriately manage $\mathrm{CO}$ and promote transparency in the scholarly publishing?

While there have been suggestions to create a central database of author $\mathrm{COI}$ and integrate it with journals and publishers, such a move may incur additional maintenance tasks and related financial expenses [3, 16].

Journal editors are encouraged to enforce the ICMJE guidelines, to conform to the Committee on Publication Ethics (COPE) statements, and to maintain the integrity of all editorial processes [18, 19]. However, COI disclosure policies are still implemented with difficulties. Some even argue that simply disclosing potential $\mathrm{COI}$ is insufficient [20] since the disclosure itself does not remove, negate, or prevent biases $[16,20]$.

The revised ICMJE Disclosure Form helps authors, reviewers, and editors to better understand what constitute $\mathrm{COI}$ and how to disclose all potential conflicts. Increasing the global awareness of the advantages of the new form is warranted to update related policies and ensure the integrity of the scholarly publishing. Authors may lack knowledge and skills for disclosing potential COI. They should be instructed to fill out the form and advised to avoid non-disclosure. The awareness of authors and other stakeholders of updates in ethical publishing [21, 22] may further increase their adherence to COI policies and management.

\section{FUNDING}

None

\section{CONFLICTS OF INTEREST}

The author has no conflicts of interest to declare.

\section{DISCLAIMER}

No part of the review was copied from or published elsewhere.

\section{REFERENCES}

1. Gasparyan AY, Ayvazyan L, Akazhanov N, Kitas GD. Conflicts of interest in biomedical publications: considerations for authors, peer reviewers, and editors. Croat Med J 2013;54(6):600-608.

2. International Committee of Medical Journal Editors. Recommendations for the Conduct, Reporting, Editing and Publication of Scholarly Work in Medical Journals. Ethical Considerations in the Conduct of Reporting of Research-Conflicts of Interest. Available from: http://www.icmje.org/recommendations/archives/2004_urm.pdf [Updated October 2004.]. Accessed Feb 8, 2021.

3. Bauchner H, Fontanarosa PB, Flanagin A. Conflicts of Interests, Authors, and Journals: New Challenges for a Persistent Problem. JAMA 2018;320(22):2315-2318.

4. International Committee of Medical Journal Editors. Recommendations for the Conduct, Reporting, Editing and Publication of Scholarly Work in Medical Journals. The Updated ICMJE Conflict of Interest Reporting Form 2010. Available from: http://www.icmje.org/news-and-editorials/ Accessed Feb 8, 2021. 
5. Taichman DB, Backus J, Baethge $\mathrm{C}$, et al. A disclosure form for work submitted to medical journals - a proposal from the International Committee of Medical Journal Editors. N Engl J Med 2020;382(7):667-668.

6. International Committee of Medical Journal Editors. Recommendations for the Conduct, Reporting, Editing and Publication of Scholarly Work in Medical Journals. Author Responsibilities-Conflicts of Interest. Available from: http://www.icmje.org/recommendations/ [Updated December 2019]. Accessed Feb 8, 2021.

7. International Committee of Medical Journal Editors. Recommendations for the Conduct, Reporting, Editing and Publication of Scholarly Work in Medical Journals. ICMJE Disclosure Form. Available from: http://www.icmje.org/disclosure-of-interest/ [Updated February 2021]. Accessed Feb 8, 2021.

8. International Committee of Medical Journal Editors. Recommendations for the Conduct, Reporting, Editing and Publication of Scholarly Work in Medical Journals. Ethical Considerations in the Conduct and Reporting of Research-Conflicts of Interest. Available from: http://www.icmje.org/recommendations/ archives/2008_urm.pdf [Updated October 2008]. Accessed Feb 8, 2021.

9. International Committee of Medical Journal Editors. Recommendations for the Conduct, Reporting, Editing and Publication of Scholarly Work in Medical Journals. Author Responsibilities-Conflicts of Interest. Available from: http://www.icmje.org/recommendations/archives/2013_aug_urm.pdf [Updated August 2013]. Accessed Feb 8, 2021.

10. Stead WW. The complex and multifaceted aspects of conflicts of interest. JAMA 2017;317(17):1765-1767.

11. International Committee of Medical Journal Editors. Recommendations for the Conduct, Reporting, Editing and Publication of Scholarly Work in Medical Journals. Roles and Responsibilities of Authors, Contributors, Reviewers, Editors, Publishers, and Owners-Conflicts of Interest. Available from: http://www.icmje.org/recommendations/archives/2018_dec_urm.pdf [Updated December 2018]. Accessed Feb 8, 2021.

12. Kelsall D. Updated CMAJ Policy on undisclosed competing interests. CMAJ 2019;191(5):E116-E117.

13. Mycyk MB. Responsible attention to conflicts of interest enhances the credibility of published scholarship. J Med Toxicol 2019;15(1):1-3.

14. Drazen JM, de Leeuw PW, Laine $C$, et al. Toward more uniform conflict disclosures - The updated ICMJE conflict of interest reporting form. N Engl J Med 2010; 363(2):188-189.

15. Ruff, K. Scientific journals and conflict of interest disclosure: what progress has been made? Environ Health 2015;14:45.

16. Dunn AG, Coiera E, Mandl KD, Bourgeois FT. Conflict of interest disclosure in biomedical research: a review of current practices, biases, and the role of public registries in improving transparency. Res Integr Peer Rev 2016;1:1.

17. Gottlieb JD, Bressler NM. How should journals handle the conflict of interest of their editors? Who watches the "watchers"? JAMA 2017;317(17):1757-1758.

18. Yessirkepov M, Gasparyan AY. From Testable Hypotheses to Ethical Papers and Improved Health Services. Cent Asian J Med Hypotheses Ethics 2020;1(1):10-13.

19. Grundy Q, Dunn AG, Bourgeois FT, Coiera E, Bero L. Prevalence of disclosed conflicts of interest in biomedical research and associations with journal impact Factors and altmetric scores. JAMA 2018;319(4):408-409.

20. Silverstein RL. In the Interest of Transparency. The Hematologist 2019;16(2) https://doi.org/10.1182/hem.V16.2.9460

21. Gasparyan AY, Yessirkepov M, Voronov AA, Gorin SV, Koroleva AM, Kitas GD. Statement on publication ethics for editors and publishers. J Korean Med Sci 2016;31(9):1351-1354.

22. Rohwer A, Young T, Wager E, Garner P. Authorship, plagiarism and conflict of interest: views and practices from low/middle-income country health researchers. BMJ Open 2017;7(11):e018467. 


\section{ХАЛЫҚАРАЛЫҚ МЕДИЦИНАЛЫҚ ЖУРНАЛДЫҚ РЕДАКЦИЯЛАРДЫҢ ХАЛЫҚАРАЛЫҚ КОМИТЕТІНІҢ ҰСЫНЫСТАРЫНА БИОМЕДИЦИЯЛЫҚ ЖАРИЯЛАНДЫРУДАҒЫ қЫЗЫқУШЫЛЫқТАРДЫң АШУЫ}

\section{Түйіндеме}

Биомедициналық зерттеулерде ықтимал мүдделер қақтығысы (ЫМқ) жиі кездесетіндіктен, мүдделер қақтығысы туралы ақпаратты ашып көрсетуімен байланысты мәселелерді шешу өзекті мәселе болып табылады. 2019 жылы медициналық журналдар редакторларының халықаралық комитеті (ICMJE) ғылыми жұмыс нәтижелерін жүргізу, сипаттау, редакциялау және медициналық журналдарда жариялау туралы ұсынымдарын қайта қарастырып, 2021 жылы ықтимал мүдделер қақтығысы туралы ақпараттың (PCP) соңғы нұсқасын ұсынды. Бұл құжаттарда ICMJE құрамына кіретін журналдарға, сондай- ақ қалған жарияланымдарға да арналған ЫМқ саясаты бойынша ұсынымдары бар. ICMJE авторлар және ғылыми жарияланымдарды жазуға қатысы бар барлық тұлғалардың ЫМқ-ны ашып көрсетуіне басымдық береді. Барлық мүдделі тараптар арасында ЫМқ-ның жаңартылған саясаты туралы жаһандық хабардарлығын арттыру журналдардың этикалық мәртебесін нығайту үшін өте маңызды болып табылады.

Түйінді сөздер: Мүдделер қақтығысы, баспа ісі, редакциялық саясат, ғылыми қоғамдар, мерзімді басылымдар тақырып ретінде

Дәйексөз үшін: Т. Кодзима. Халықаралық медициналық журналдық редакциялардың халықаралық комитетінің ұсыныстарына биомедициялық жарияландырудағы қызықушылықтардың ашуы. Медициналық гипотеза мен этиканың Орта Азиялық журналы. 2021; 2 (1): 18-22. https:// doi.org/10.47316/cajmhe.2021.2.1.03

\section{РАСКРЫТИЕ ПОТЕНЦИАЛЬНЫХ КОНФЛИКТОВ ИНТЕРЕСОВ В БИОМЕДИЦИНСКИХ ПУБЛИКАЦИЯХ В СООТВЕТСТВИИ С РЕКОМЕНДАЦИЯМИ МЕЖДУНАРОДНОГО КОМИТЕТА РЕДАКТОРОВ МЕДИЦИНСКИХ ЖУРНАЛОВ}

\section{Резюме}

Поскольку потенциальные конфликты интересов (COI) являются обычным явлением в биомедицинских исследованиях, решение проблем, связанных с раскрытием информации о конфликтах интересов, является актуальным вопросом. Международный комитет редакторов медицинских журналов (ICMJE) в 2019 году пересмотрел свои рекомендации по проведению, описанию, редактированию и публикации результатов научной работы в медицинских журналах и представил последнюю версию формы раскрытия потенциального конфликта интересов (ПКИ) в 2021 году. Эти документы содержат рекомендации относительно политики ПКИ для журналов, которые входят в ICMJE, а также для остальных изданий. ICMJE уделяет приоритетное внимание раскрытию ПКИ авторами и всеми другими лицами, участвующими в написании научных публикаций. Повышение глобальной осведомленности об обновленной политике ПКИ среди всех заинтересованных сторон имеет важное значение для укрепления этического статуса журналов.

Ключевые слова: Конфликт интересов, издательское дело, редакционная политика, научные общества, периодические издания как тема

Для цитирования: Т. Кодзима. Раскрытие потенциальных конфликтов интересов в биомедицинских публикациях в соответствии с рекомендациями международного комитета редакторов медицинских журналов. Центральноазиатский журнал медицинских гипотез и этики. 2021; 2 (1): 18-22. https:// doi.org/10.47316/cajmhe.2021.2.1.03 